九州大学学術情報リポジトリ

Kyushu University Institutional Repository

\title{
The Present and Future Land Management in East Timor : from "Slush and Burn" to "Slush and Mulch"
}

Egashira, Kazuhiko

Faculty of Agriculture, Kyushu University

Gusmao, Marcal N-A

Faculty of Agriculture, National University of Timor Leste

Kurosawa, Kiyoshi

Institute of Tropical Agriculture, Kyushu University

https://doi.org/10.5109/9255

出版情報：九州大学大学院農学研究院紀要. 51 (2)，pp.367-372，2006-10-27. Faculty of Agriculture, Kyushu University

バージョン：

権利関係 : 


\title{
The Present and Future Land Management in East Timor - from "Slush and Burn" to "Slush and Mulch" -
}

\author{
Kazuhiko EGASHIRA*, Marcal N/A GUSMAO' \\ and Kiyoshi KUROSAWA ${ }^{2}$ \\ Laboratory of Soil Science, Division of Soil Science and Plant Production, \\ Department of Plant Resources, Faculty of Agriculture, \\ Kyushu University, 812-8581 Fukuoka, Japan \\ (Received June 27, 2006 and accepted July 24, 2006)
}

\begin{abstract}
In East Timor land degradation has become severe by continuation of the traditional land management of "slush and burn" with shortening or elimination of the fallow period and by conversion of forestry land into agricultural land forced by increase in agricultural production. Population pressure, triggered by independence of the country, is one of the causes for land degradation. The present situations of land use and land management in East Timor are introduced, followed by the statement of land degradation occurring in the country. Practices for future improvement of land management to prevent agricultural land from degradation are recommended.
\end{abstract}

\section{INTRODUCTION}

Republica Democratica Timor-Leste (RDTL) or Democratic Republic of East Timor won independence on 30th August 1999 by voting and became fully independent on 20 May 2002, after colonization by Portugal for about 450 years from 1520 to 1974 followed by civil war between opposing political parties and fighting against Indonesia during 1975 and 2002 (Gusmao, 2006). In July 2005 after independence population of the country was estimated to be 800,000 with an estimated population density of 54 persons per $\mathrm{km}^{2}$ and with an estimated annual population growth rate of 2.09\%. The Government has 13 ministries. Among them, major roles and responsibility of the Ministry of Education \& Culture are development and coordination of national policies, plans and programs in education, and those of the Ministry of Agriculture, Forestry \& Fisheries are policy formulation, economic coordination and planning in respect of food grain, agricultural and livestock production. Universidade Nacional Timor Lorosa's (UNTL) or National University of Timor-Leste is only one public university in East Timor, leaving other 11 universities as private university.

"Special Course on Contemporary Japan for National University of Timor-Leste Faculty Members", sponsored by Toshiba International Foundation, was held at Kyushu University during 20 February and 10 March 2006, implemented by Faculty of Agriculture, Institute of Tropical Agriculture, and Office for the Planning and Coordination of International Affairs. Three faculty members of the Faculty of Agriculture, UNTL joined the 3-week course. The present program was the first training program of Kyushu University to faculty members of

\footnotetext{
${ }^{1}$ Faculty of Agriculture, National University of Timor Leste, Dili, Timor Leste

${ }^{2}$ Institute of Tropical Agriculture, Kyushu University, Fukuoka 812-8581, Japan

* Corresponding author (E-mail: kegashi@agr.kyushu-u.ac.jp)
}

UNTL and was focused on the Faculty of Agriculture. This is because agriculture forms the basis or foundation of nation-building and because the Faculty of Agriculture and the Institute of Tropical Agriculture of Kyushu University have solid performance and accomplishments in the technical cooperation to agricultural universities of Asian countries. In the current article, general features of East Timor are first outlined, and the present land use and land management, and land degradation occurring in East Timor are introduced and the future improvement of management practices is discussed as a result of the activity in the program.

\section{OUTLINE OF EAST TIMOR}

East Timor is outlined according to the information given by the country report on East Timor presented on the first day (20 February 2006) of the "Special Course on Contemporary Japan for National University of Timor-Leste Faculty Members" (Gusmao, 2006).

\section{Language}

Official language is Portuguese and national language is Tetum. There are 16 indigenous languages (dialects); among them Tetum, Galole, Mambae, Makasae and Kemak are spoken by significant numbers of people. Indonesian and English are also used.

\section{Geography}

East Timor is a country in Southeast Asia. Main part of the country is situated at 8.5 to $9.7^{\circ} \mathrm{S}$ and 124.9 to $127.3^{\circ} \mathrm{E}$ and is located in northwest of Australia in the Lesser Sunda Islands at the end of the Indonesia Archipelago. Timor Island particularly East Timor is well known as the island of mountains and hills. Mountainous and hilly areas occupy about $72 \%$ of the country.

\section{Climate}

East Timor belongs to tropical monsoon climate. 
The short wet season (wet monsoon) ranges from November to March and the long dry season (dry monsoon) from April to October. Temperature is 18 to $21^{\circ} \mathrm{C}$ in the wet season and 26 to $32^{\circ} \mathrm{C}$ in the dry season. Two rainfall patterns occur in East Timor. One is the monomodal rainfall pattern in the northern region, in which the wet season is 4 to 6 months with a single rainfall peak between December and February. The other is the bimodal rainfall pattern in the southern region, in which the wet season continues for 7 to 9 months and there are two rainfall peaks at December to February in the first and at May to June in the second. The rainfall patterns impact agricultural activities in the country. Low annual rainfall of 800 to $1,500 \mathrm{~mm}$ in the coastal areas of the northern region limits crop production by drought. The amount of rainfall significantly increases with the increasing elevation, and annual rainfall amounts up to 3,000 $\mathrm{mm}$ in the upland areas.

\section{Agriculture}

Three main staple food crops in the country are rice, maize and cassava. The mean annual crop production between 1990 and 1994 of East Timor in the Indonesia time is as follows (Mg): rice, 60,720; maize, 99,880; cassava, 59,360; sweet potato, 14,340; vegetables, 13,400; groundnut, 2,980; green pea, 2,840; and soybean, 904 .

\section{Economy}

Agriculture has contributed mainly to the economy of East Timor for many years and is expected to fulfill it in the future. GDP per capita is estimated to be $\$ 400$ in 2004. Imports are over exports; the country imports rice, automobiles, electronic devices, etc. and exports coffee.

\section{Development in the society}

In 1999 at the final stage of the civil war, about 70\% of the economic infrastructure of East Timor was destroyed. 300,000 people fled westward in this period. Over the next three years, however, a massive international aid program led to substantial reconstruction in both urban and rural areas. By 2003 all but about 30,000 of the refugees had returned. But, the country still faces to strained circumstances in social, political, economical and educational aspects. Hard and soft cooperation is urgently required.

\section{GENERAL LAND USE IN EAST TIMOR}

East Timor has $14,874 \mathrm{~km}^{2}$ of national land. Suitable or potential agricultural land is $6,000 \mathrm{~km}^{2}$, occupying $40.3 \%$ of the national land. In contrast, forestry land covered with trees is only $285 \mathrm{~km}^{2}$, equivalent to $1.9 \%$ of the national land. The value of $1.9 \%$ is absolutely low compared to $72 \%$ of the occupation by the mountainous area in the country. It may indicate rapid progress of deforestation, leaving unused shrubland behind. The combined planted area of paddy rice and upland rice is $43.55 \mathrm{~km}^{2}$. The area of rice land is $10.65 \mathrm{~km}^{2}$. Under the assumption that the area of rice land is equivalent to the planted area of paddy rice, the planted area of upland rice is calculated to be $32.90 \mathrm{~km}^{2}$. The planted area is 3.1 times larger for upland rice than for paddy rice. The planted area of maize is $504 \mathrm{~km}^{2}$ and larger by 11.6 times than the combined planted area of paddy and upland rice. The planted area of coffee, which is a most important exporting crop in East Timor, is $290 \mathrm{~km}^{2}$ in Ermera district where most intensive coffee production is carried out. Statistical values shown in the above were quoted from different sources of different years, and they are considered to give just general idea or information on the land use in East Timor.

\section{PRESENT LAND MANAGEMENT}

\section{Cultivation of major crops}

Paddy rice

Paddy rice is cultivated once a year depending on the rainfall conditions or availability of water resources. Paddy rice is transplanted or directly sown in March to April and harvested in June through August in the northern region while transplanted or directly sown in May to June and harvested August through October in the southern region. Cultivation periods of paddy rice cover the end or late phase of the rainy season to the major part of the dry season. Distribution of paddy field is little in the low-lying area and much in the upland area. Paddy field is terraced in the upland area.

Concerning the yield of paddy rice an average of around $2.5 \mathrm{Mg} / \mathrm{ha}$ has been reported. According to the other source, the rice yield including both paddy and upland rice is estimated to be 0.5 to $2.0 \mathrm{Mg} / \mathrm{ha}$. Multiplication of the value of $2.5 \mathrm{Mg} / \mathrm{ha}$ with the rice land area of $10.65 \mathrm{~km}^{2}$ gives the paddy rice production of $2,663 \mathrm{Mg}$, which is below one-twentieth of the value of $60,720 \mathrm{Mg}$ reported in the above as the mean annual rice production between 1990 and 1994 of East Timor in the Indonesia time. Multiplication of the yield of $2.0 \mathrm{Mg} / \mathrm{ha}$ with the combined planted area of paddy and upland rice of $43.55 \mathrm{~km}^{2}$ gives the rice production of $8,710 \mathrm{Mg}$. Even this value is only one-seventh of $60,720 \mathrm{Mg}$. There may be some miscounting in the statistical values on rice cultivation, and further verification is necessary.

Maize (main crop)

Maize (main crop) is cultivated mostly in the rainy season and planted in November to December and harvested in March to April. Yield of maize is $0.7 \mathrm{Mg} / \mathrm{ha}$ in poor soil and 1.3 to $1.5 \mathrm{Mg} / \mathrm{ha}$ in fertile soil.

Maize (off-season crop)

Cultivation of maize (off-season crop) is very limited due to lack of water resources. It is planted in May through August and harvested in September to October. Cassava

Cassava is planted from November to February at the beginning of the rainy season and is harvested in all months up to the 3rd year after planting. Yield of cassava is 2 to $4 \mathrm{Mg} / \mathrm{ha}$.

Sweet potato

Sweet potato is planted in the period of November through January and harvested from April to September. 
Coffee

Coffee is a cash crop, leaving rice, maize, sweet potato and cassava as food security crops. Coffee is cultivated by farmers and the products are collected by the international company based in East Timor.

\section{Mixed cropping of upland crops in the upland area}

Upland crops are cultivated in the mixed cropping (or multiple cropping) as a combination of maize, cassava and sweet potato under the rain-fed condition. Those crops are mostly consumed by farm households themselves and are not sold to markets, and are regarded as subsistence crops for living. The mixed cropping is a traditional cultivation method of upland crops in East Timor to keep food security for farm households. In the mixed cropping upland crops are mostly cultivated without terracing; some terracing but poor management. Different crops are cultivated in the same field and planted randomly at the beginning of the rainy season. Planting pattern in the mixed cropping is shown schematically in Fig. 1, and upland rice is probably included in it depending on the farms.

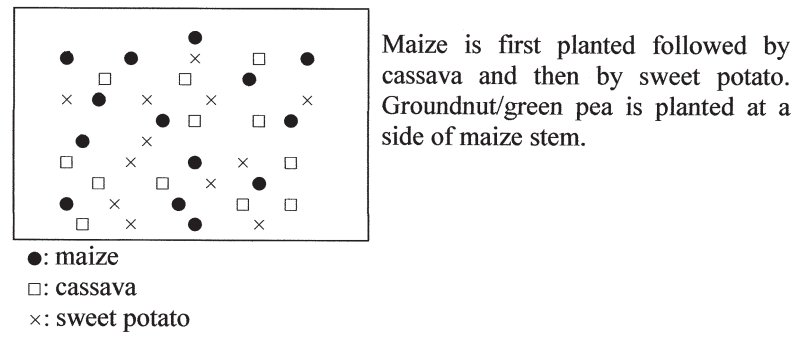

Fig. 1. Planting pattern in the mixed cropping.

\section{Slush and burn (shifting cultivation)}

Slush and burn is done all the time in the agricultural area in East Timor. In the mixed cropping of upland crops, crop residues are burned out after harvest of all crops or at the time when land preparation occur for the next planting season. The reasons for burning of crop residues are 1) easy for land preparation and 2) easy for weed control. In the past, shifting cultivation was well practiced by farmers with the sustainable land management and the fallow periods up to 15 years was common. However, the fallow period has been shortened due to limitation of land availability mainly caused by increasing number of population. Slush and burn but no shifting is prevailing with a result of conversion from shifting cultivation into continuous cultivation. This tendency or change in the slush and burn cultivation is not only limited to East Timor but is occurring widely with accelerating speed in the mountainous regions of the tropical to subtropical monsoon Asia, and a case study in the northern Thailand was introduced in detail by Hirai and Hirai (2004). Shortening or elimination of the fallow period in the slush and burn cultivation obliges farmers to apply chemical fertilizers and agricultural chemicals for sustaining crop yield.

\section{LAND DEGRADATION OCCURRING IN THE COUNTRY}

According to FAO, UNDP and UNEP (1994) land degradation is defined as the temporary or permanent lowering of the productive capacity of land. The term land refers not just to soil, but all natural resources which contribute to agricultural production. In a comprehensive study on land degradation in South Asia by FAO, UNDP and UNEP (1994), three degrees of severity of degradation were recognized: light: somewhat reduced agricultural productivity; moderate: greatly reduced agricultural productivity; and strong: not capable of agricultural production, and unreclaimable at farm level. The following types of land degradation were assessed: water erosion; wind erosion; soil fertility decline; waterlogging; salinization; lowering of water table. Three other types were considered in more generalized terms: deforestation; forest degradation; rangeland degradation.

Almost all types of land degradation are occurring in East Timor. They are soil erosion, soil fertility decline, sedimentation of eroded soil on the agricultural land, and soil acidification. In addition, lacking of water resources, and drought and flooding threaten agricultural production.

Soil erosion

The most significant problem is soil erosion in land degradation in East Timor. Soil erosion from the forestry land is due to: 1) conversion of forestry land into agricultural land and 2) cutting of trees for fuel. Repeated burning of natural resources for shifting cultivation and hunting in the dry season have exposed soil to erosion. Soil erosion from the agricultural land is mainly due to slush and burn, in which after burning no crop cover remains in the field at the start of the rainy season. It is just a condition prone to water erosion, because land cover is always important in the rainy season in preventing soil from erosion.

Soil fertility decline

Decline in the soil fertility is evaluated from the organic matter content in soil and is a second most significant problem in land degradation in East Timor. In a site where alley cropping is tested, soil organic matter content of the experimental plots was as low as 10 to $13 \mathrm{~g} / \mathrm{kg}$ and was considerably below $20 \mathrm{~g} / \mathrm{kg}$ which is generally regarded as the critical level for soil organic matter content. The bulk density of soil at the same experimental plots was as high as 1.25 to 1.49 and 1.34 to $1.63 \mathrm{Mg} / \mathrm{m}^{3}$. The high bulk density, associated with the low organic matter content, is indicative of the reduced status of soil fertility and destruction of soil structure brought about by the poor land management. Sedimentation of eroded soil on the agricultural land

Soil erosion not only degrades the eroded sloping land but also destructs the low-lying agricultural land by deposition of eroded soil on it. This is a typical indication how severely soil erosion degrades the national 
land. Physical removal of sediments from the agricultural land is difficult because of high labor cost. Change of crops from paddy rice to maize and cassava is often selected instead.

Soil acidification

Soil acidification occurs in upland soils. Soil pH in some upland soils is reported to be around 5 in average. Application of lime is a way for remediation of soil acidity but is costly because of import of lime from Indonesia. Planting of acid-tolerant crops, especially sweet corn, potato and groundnut, is a selected solution. Lacking of water resources

Main water resources in East Timor are rainfall, spring and river. It means that water resources depend extremely on the rainfall amount and distribution of that year and of the specified area or region. In the future, competition of the use of water resources among industrial, commercial, municipal and agricultural sectors will be strengthened. Concerning the irrigation system in East Timor, it is mainly the surface irrigation and irrigation water comes from spring and river. In the surface irrigation no pumping is used and water flows through irrigation channels by gravity.

\section{FUTURE LAND MANAGEMENT}

\section{Reforestation}

In order to prevent the forestry land from deforestation and to keep the forestry land in a covered condition, reforestation plans are going on in the Government and the local and international NGOs. Reforestation programs should be urgently pushed forward. Concerning cutting of trees in a forest for fuel by local people, Tara Bandu which is a prevention technique of forest based on the traditional culture may serve a useful reference to protection of the forest from over-harvesting and illegal logging.

\section{Trial for conservation of soil from degradation}

The idea for this trial is growing of leguminous tress and crops and application of them after cutting to the field as mulch, because farmers do not apply chemical fertilizers and any other amendments to the field in the upland cultivation. As leguminous trees sesban which is a narrow-crowned, deep-rooting single or multi stemmed shrub or small tree, 1-7 m tall, and easily forms root nodule (stem nodule), and leucaena which is a highly nutritious pasture legume tree with about $6 \mathrm{~m}$ tall and grows thick in the alkaline soil of the tropics and subtropics, are usually used. The aims of this trial are to prevent soil from direct attack by raindrops and from occurrence of surface runoff and to keep soil fertile. The following two methods are under examination in the farmer's field.

Planting of macuna (velvet bean) with maize in the mixed condition

Macuna is planted with maize in the mixed condition followed by cutting and mulching. Alley cropping of leguminous trees

Alley cropping is generally illustrated in Fig. 2.

$\begin{aligned} & \text { crops such as maize, sweet } \\ & \text { potato and cassava }\end{aligned}$
$\begin{aligned} & \text { crops such as maize, sweet } \\ & \text { potato and cassava }\end{aligned}$

Fig. 2. General illustration of alley cropping.

Several kinds of leguminous trees are planted in alley and crops are planted in between alley rows. After cutting they are used as mulch to surface of the field. In addition, a part of cut leguminous trees can be used for fuel to suppress cutting of trees in a forest.

\section{Conversion from "Slush and Burn" into "Slush and Mulch"}

Mulching of the land surface by organic materials is the most simple but effective practice for prevention of soil from soil erosion and soil fertility decline. Crop residues like maize stalks and weeds, compost made of livestock excretions and fallen tree leaves are considered as appropriate and available mulching materials, in addition to macuna and leguminous trees in alley cropping. Farmers can easily get those materials and apply them on the land surface. Hirai and Hirai (2004), quoted in the above, have proposed the following application of organic materials for improvement of soils degraded under shifting cultivation: putting sufficient amounts of fallen tree leaves in themselves or mixed with livestock excretions on the top of soil, followed by covering them by weeds, rice straws and maize stalks. It activates small animals and microorganisms in soil and hence improves soil structure and soil fertility status suitable for crop production. Enrichment of organic matter in soil also increases the water holding capacity of soil. Conversion from "Slush and Burn" into "Slush and Mulch" is strongly recommended. It is a simple and suitable technique to prevent soil from degradation and to keep soil alive. Making soil healthy leads to improvement of both quantity and quality in crop production.

\section{Improvement of irrigation system}

This is a big problem and should be a national project by the Ministry of Agriculture, Forestry \& Fisheries. One idea in a local level task for keeping irrigation water is the seasonal establishment of simple and small irrigation facilities in a river using materials available in the area. One example is construction of a movable weir by wood and plant leaves to reserve river water. Another idea is making of a small pond near the farming area for irrigation use.

\section{APPENDIX - Education System in the Faculty of Agriculture, UNTL}

\section{Organization of UNTL}

UNTL was called Universitas Timor Timur in the 
Indonesian time and consisted of Faculties of Education, Agriculture, Social Politic and Economy. The University was integrated with Dili Polytechnic in 2000, called Universidade Nacional Timor Lorosa'e, and presently consists of the following seven Faculties: Education, Social Politic, Economy, Engineering, Law, Medicine and Agriculture.

\section{Organization of the Faculty of Agriculture, UNTL}

The Faculty of Agriculture of UNTL consists of three Departments of Agronomy, Social Economic Agriculture and Animal Science with faculty members (all Lecturers) of 8, 10 and 14, respectively. Among 32 Lecturers in total, 8 persons get the Master Degree and the remaining 24 persons have only the Bachelor Degree.

\section{Major fields of the faculty members of the Department of Agronomy, Faculty of Agriculture, UNTL}

Major fields of the 8 Lecturers of the Department of Agronomy are shown in Table 1. Major fields of them are concentrated to subjects related to Soil Science, Plant Science and Agricultural Technology.

Table 1. Major fields of eight Lecturers in the Department of Agronomy, Faculty of Agriculture, UNTL

\begin{tabular}{ll}
\hline No. & Major field \\
\hline 1 & Soil \& Water Conservation; Irrigation Science \\
2 & Plant Ecology; Plant Physiology \\
3 & Soil Science; Soil Fertility \\
4 & Soil Microbiology \\
5 & Plant Physiology; Research Methodology \\
6 & Plant Protection \\
7 & Post Harvest Technology; Climatology \\
8 & Weed Management \\
\hline
\end{tabular}

Curriculum of the Department of Agronomy, Faculty of Agriculture, UNTL

Curriculum of the Department of Agronomy is listed in Table 2. The term of study in the Faculty of Agriculture of UNTL is 5 years and 155 credits are required to students for graduation (Almeida, 2006). Two credits mean 16 times of lecture of 1 hour 45 minutes in one time. In addition to fulfillment of the credit, a student must conduct a workshop and then a research based on the title of his final assignment. The period of the research is 1 to 3 months, and the type of the research is survey in the field, survey in local breeders, or experiment in laboratory and field.

\section{ACKNOWLEDGEMENTS}

We express our sincere thanks to Toshiba International Foundation for the financial support. We also show our gratitude to faculty members and staffs of the Faculty of Agriculture, the Institute of Tropical Agriculture and the Office for the Planning and Coordination of International Affairs, Kyushu University, for their nice arrangement and management and heartful assistance to successful and fruitful performance of the training program.

\section{REFERENCES}

Almeida, A. D. 2006 Country report: Faculty of Agriculture, National University of Timor Lorosa'e. In "Special Course on Contemporary Japan for National University of Timor-Leste Faculty Members" (Mimeographed), Fukuoka

FAO, UNDP and UNEP 1994 Land Degradation in South Asia: Its Severity, Causes and Effects upon the People. World Soil Resources Reports 78. FAO, Rome (Italy), 100 pp.

Gusmao, M. N/A 2006 Country report. In "Special Course on Contemporary Japan for National University of Timor-Leste Faculty Members" (Mimeographed), Fukuoka

Hirai, H. and M. Hirai 2004 Having a view of "sustainable development" at slush and burn villages. In "Taking off in Agriculture of Southeast Asia", ed. by K. Natsuaki and K. Itagaki, Norin Tokei Kyoukai, Tokyo, pp. 69-101 (in Japanese) 
Table 2. Curriculum of the Department of Agronomy, Faculty of Agriculture, UNTL

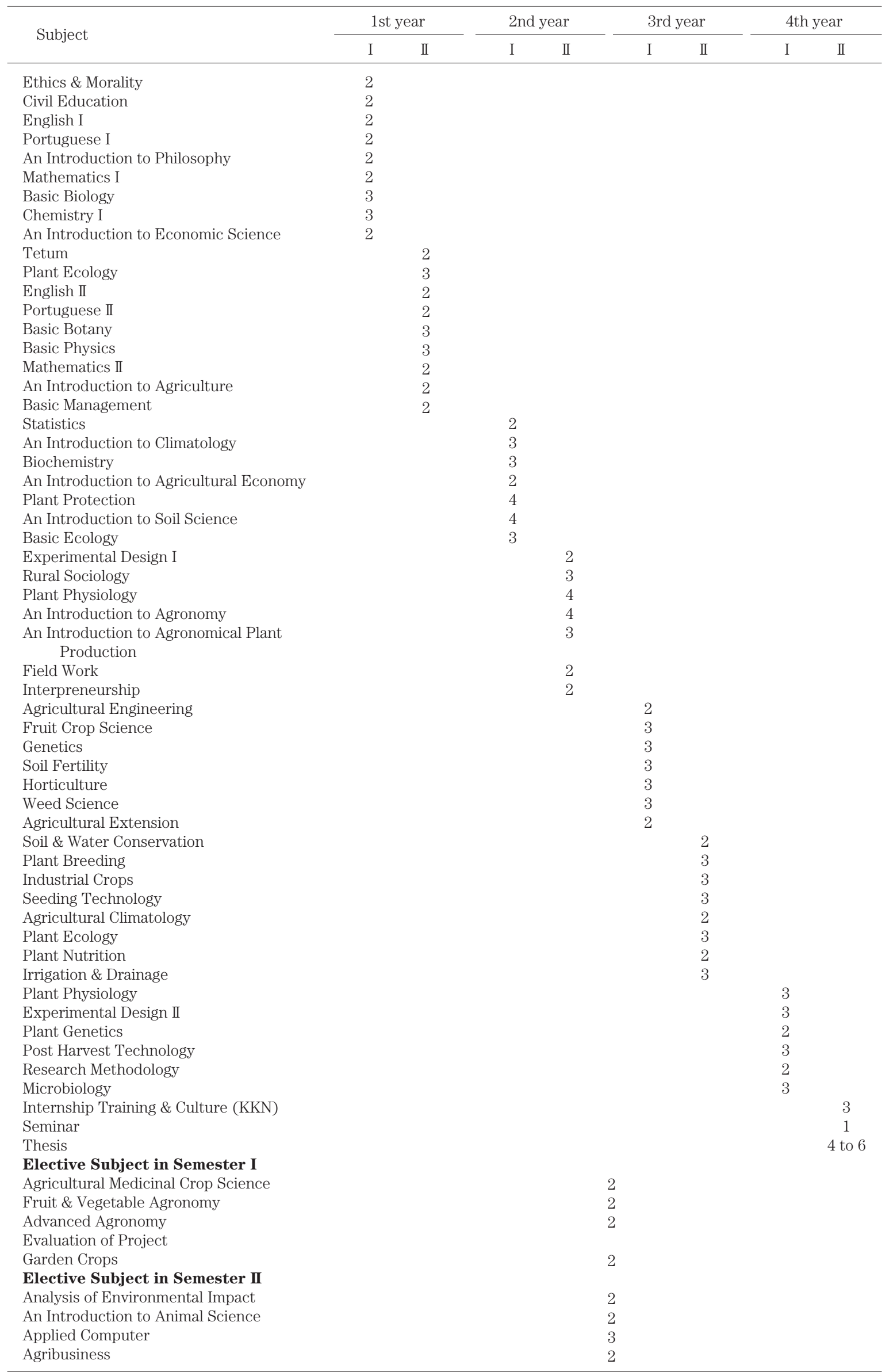

I: Semester I; II: Semester II. Figures in the Table are credit. 